Research Paper: Neuroscience

\title{
5d, a novel analogue of 3-n-butylphthalide, decreases NADPH oxidase activity through the positive regulation of CK2 after ischemia/reperfusion injury
}

\author{
Jia Zhou ${ }^{1, *}$, Yi-hua Zhang ${ }^{2, *}$, Hui-zhu Song ${ }^{3}$, Hui Ji ${ }^{2}$, Xiao-li Wang ${ }^{1}$, Lei Wang ${ }^{3}$, Jun \\ Qian ${ }^{3}$, Jing-jing Ling ${ }^{3}$ and Feng-feng Ping ${ }^{3}$ \\ ${ }^{1}$ School of Pharmaceutical Science, Jiangnan University, Wuxi, P.R. China \\ 2 State Key Laboratory of Natural Medicines, Center of Drug discovery, China Pharmaceutical University, Nanjing, P.R. China \\ ${ }^{3}$ Wuxi People's Hospital affiliated to Nanjing Medical University, Wuxi, P.R. China \\ * These authors have contributed equally to this work \\ Correspondence to: Jing-jing Ling, email: lingjingjing77@163.com \\ Feng-feng Ping, email: pfftile@163.com \\ Keywords: 5d; neuroprotection; CK2; NADPH oxidase; ROS; Neuroscience \\ Received: December 07, 2015 Accepted: May 05, $2016 \quad$ Published: May 12, 2016
}

\section{ABSTRACT}

$5 d$, a novel analogue of the racemic 3-n-butylphthalide (NBP), has been reported for its free radical scavenging activity in vitro and preventive neuroprotection in vivo. Nevertheless, the mechanism by which $5 \mathrm{~d}$ attenuated ischemia/reperfusion $(I / R)$ injury is still unknown. Our results showed that $5 d$ significantly increased CK2 activity as well as CK2a and $2 a^{\prime}$ protein levels after I/R injury. Besides, $5 d$ suppressed the translocation of cytosolic p47phox and Rac1 to the membrane, decreased NOX4 expression and ROS generation. Furthermore, $5 \mathrm{~d}$ blocked the dissociation between CK2 $a$ and Rac1 so as to decrease NADPH oxidase activity. Based on these findings, we propose that the neuroprotective effect of $5 d$ is due to an increase of CK2 activity, which blocks I/R-induced dissociation between CK2a and Rac1, decreases NADPH oxidase activity, inhibits ROS production and finally realizes the neuroprotection of I/R. These findings point to that $5 \mathrm{~d}$ might be considered an attractive candidate for further studies in ischemic stroke.

\section{INTRODUCTION}

Strokes are the leading cause of permanent disability and death worldwide. Due to the occlusion of a vessel in the brain, ischemic strokes account for the majority of strokes $[1,2]$. After brain ischemia, the increased oxidative stress has been considered as a primary cause for brain injury due to oxidation of proteins and nucleic acids, and peroxidation of lipid induced by free radical [3, 4]. The application of free radical scavengers as potential treatments for ischemic stroke has attracted more and more attention $[5,6]$.

3-n-butylphthalide (NBP) has been approved by State Food and Drug Administration (SFDA) of China as a new drug for treating ischemic stroke [7]. Using NBP as the parent compound, we designed 3-butylbenzo[c] thiophen-1(3H)-one, named $5 \mathrm{~d}$, a new analogue of the racemic NBP. To improve its therapeutic effect, NBP is often administered with anti-platelet and/or antioxidant drug(s) [8]. Interestingly, it has been recently reported the actions of $5 \mathrm{~d}$ against free radicals, platelet aggregation, thrombosis and cerebral ischemia [9]. Nevertheless, the mechanism of $5 \mathrm{~d}$ against cerebral ischemia is still unknown.

NADPH oxidases are known to be the only enzyme family producing reactive oxygen species (ROS) as their sole and primary function $[10,11]$. As the multiprotein complexes, they are comprised of a catalytic, transmembrane-spanning subunit (NOX) and several structure and regulatory proteins which localized in both the cytosol and the membrane [12]. To activate NADPH oxidase, cytosolic subunits guanosine 5'-triphosphate (GTP)-Rac1, p67phox and p47phox migrate from cytoplasm to the membrane forming the active NADPH 
oxidase complex $[13,14]$. It has been reported that protein kinase CK2 protects against cerebral ischemia through the negative regulation of NADPH oxidase [15]. CK2 is a highly conserved protein kinase. It has a growing list of more than 300 substrates and the majority are proteins implicated in nuclear functions such as ubiquitination, cell survival, gene expression, signal transduction, and RNA synthesis $[16,17]$. In recent years, the study on the role of CK2 in cerebral ischemia has received more and more attention of researchers [15, 18, 19].

In the present experiment, the middle cerebral artery occlusion (MCAO) was used as an in vivo model, while the oxygen-glucose deprivation/reoxygen (OGD/R) was used as an in vitro model. The aim of this text is to investigate whether $\mathrm{CK} 2$ and/or NADPH oxidase are involved in neuroprotection of $5 \mathrm{~d}$ against the cerebral ischemia and its relevant mechanism.

\section{RESULTS}

\section{5d elevated CK2 activity in an in vivo MCAO model and in vitro $\mathrm{OGD} / \mathrm{R}$ model}

As shown in Figure 1, compared with the Sham groups, CK2 activity was remarkably reduced in the brains of Model groups. 5d elevated CK2 activity after I/R. To reveal which subunit was involved in $5 \mathrm{~d}$-induced increase of CK2 activity, we then assessed the levels of CK $2 \alpha, 2 \alpha$ and $2 \beta$ protein expression. The levels of CK $2 \alpha$ and $2 \alpha$ ' protein expression were strongly decreased in the brains of Model groups verses that of Shams. 5d significantly up-regulated CK $2 \alpha$ and $2 \alpha^{\prime}$ protein expression after I/R injury. However, the expression of CK $2 \beta$ protein between groups did not show any differences (Figure 2).

To confirm the changes of $\mathrm{CK} 2$ subunits protein expression, the primary cortical neuronal culture was subjected to OGD/R injury. As with the in vivo data, pretreatment with $5 \mathrm{~d}$ profoundly attenuated the downregulation of CK $2 \alpha$ and $2 \alpha^{\prime}$ protein expression induced by $\mathrm{OGD} / \mathrm{R}$, whereas there was no influence on the levels of CK2 $\beta$ protein expression (Figure 3 ).

\section{$5 d$ decreased the level of NOX4 protein expression after $\mathbf{I} / \mathbf{R}$}

NADPH oxidases are known to be the only enzyme family with the sole function of producing ROS. NOX4, as the most widely distributed isoform of the catalytic NADPH oxidase subunits (NOX), has been demonstrated to be a promising therapeutic target for diseases including stroke, fibrosis, and heart failure. Accordingly, in the current study, we detected the level of NOX4 protein expression in the brains of rats. Results showed that the level of NOX4 expression was up-regulated in the brains of Model group compared with that of Shams. $5 \mathrm{~d}$ strongly down-regulated the level of NOX4 expression after I/R injury (Figure 4).

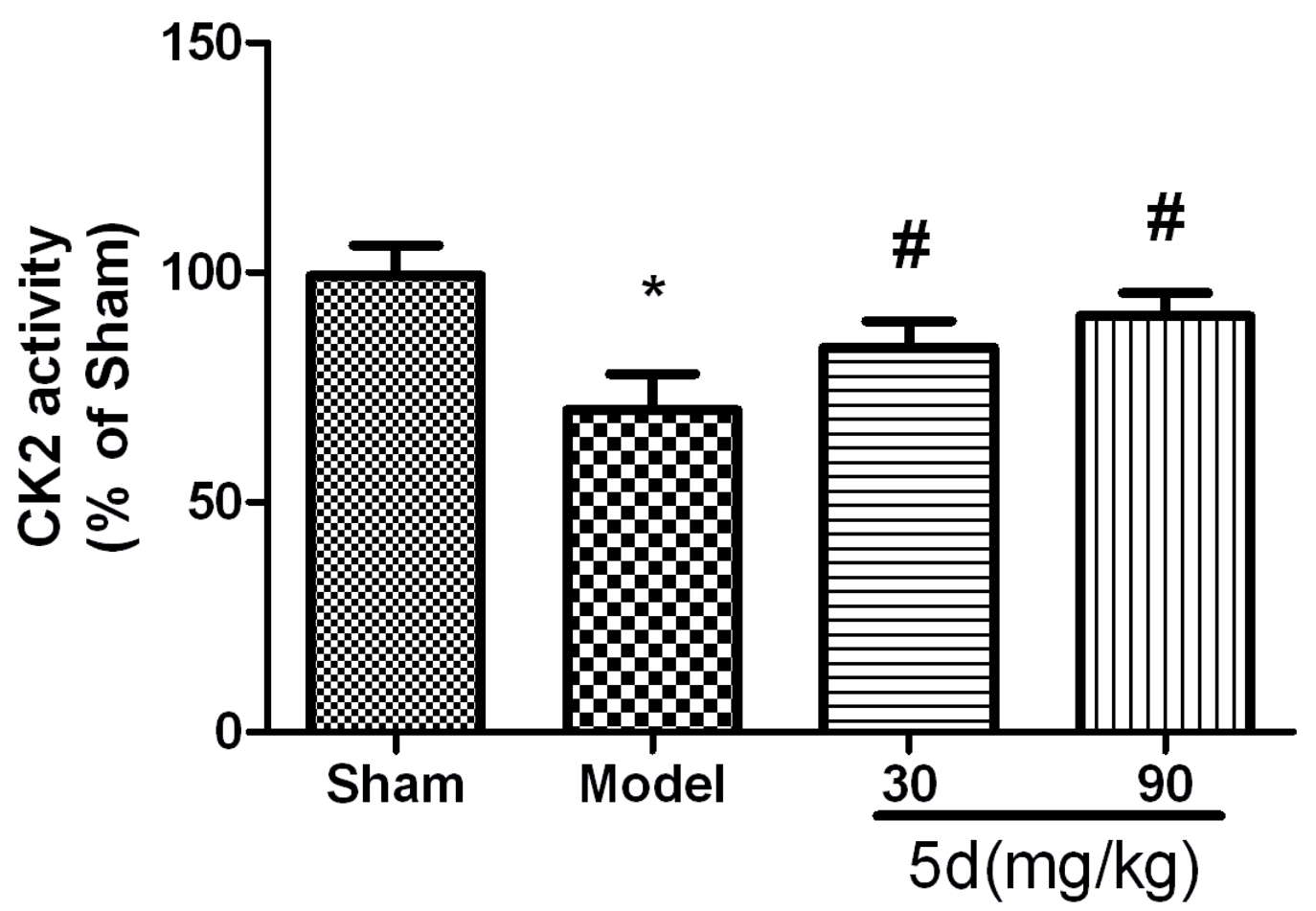

Figure 1: Effects of $\mathbf{5 d}$ on CK2 activity in the brains of rats after $\mathbf{I} / \mathbf{R}$. Data are expressed as means $\pm \operatorname{SD}(n=6)$. ${ }^{*} P<0.05 v s$ Sham group. ${ }^{\#} P<0.05$ vs Model group. 
To define the role of CK2 in 5d-induced downregulation of NOX4 expression after $\mathrm{I} / \mathrm{R}$, a primary neuronal culture was subjected to $\mathrm{OGD} / \mathrm{R}$ with the transfection of CK2 $\alpha$-specific siRNA before $5 \mathrm{~d}$ treatment. Figure $5 \mathrm{~A}$ showed that in comparison with untransfected or scrambled-transfected primary neuronal cells, the level of CK $2 \alpha$ protein expression was significantly decreased by $24 \mathrm{~h}$ with the transfection of CK $2 \alpha$ siRNA. Besides, CK2 down-regulation remarkably reduced neuronal viability in response to $\mathrm{OGD} / \mathrm{R}$ injury. It is worthy to mention that the improvement of $5 \mathrm{~d}$ on neuronal survival was markedly curtailed in CK2siRNA-transfected neurons (Figure 5B). Moreover, blocking CK $2 \alpha$ protein expression in cortical primary neurons impaired the effect of $5 \mathrm{~d}$ on decreasing the level of NOX4 protein expression after OGD/R injury (Figure 6).

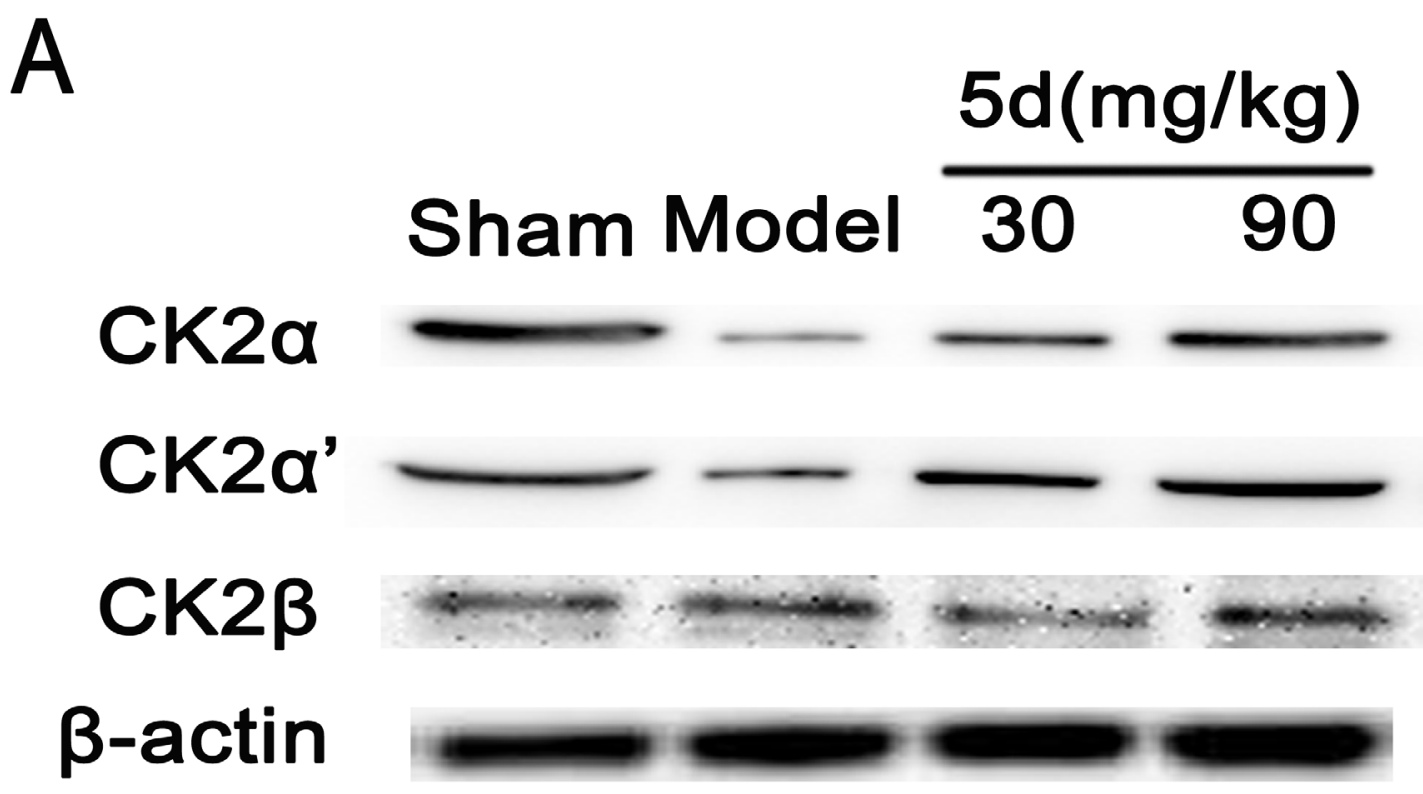

B

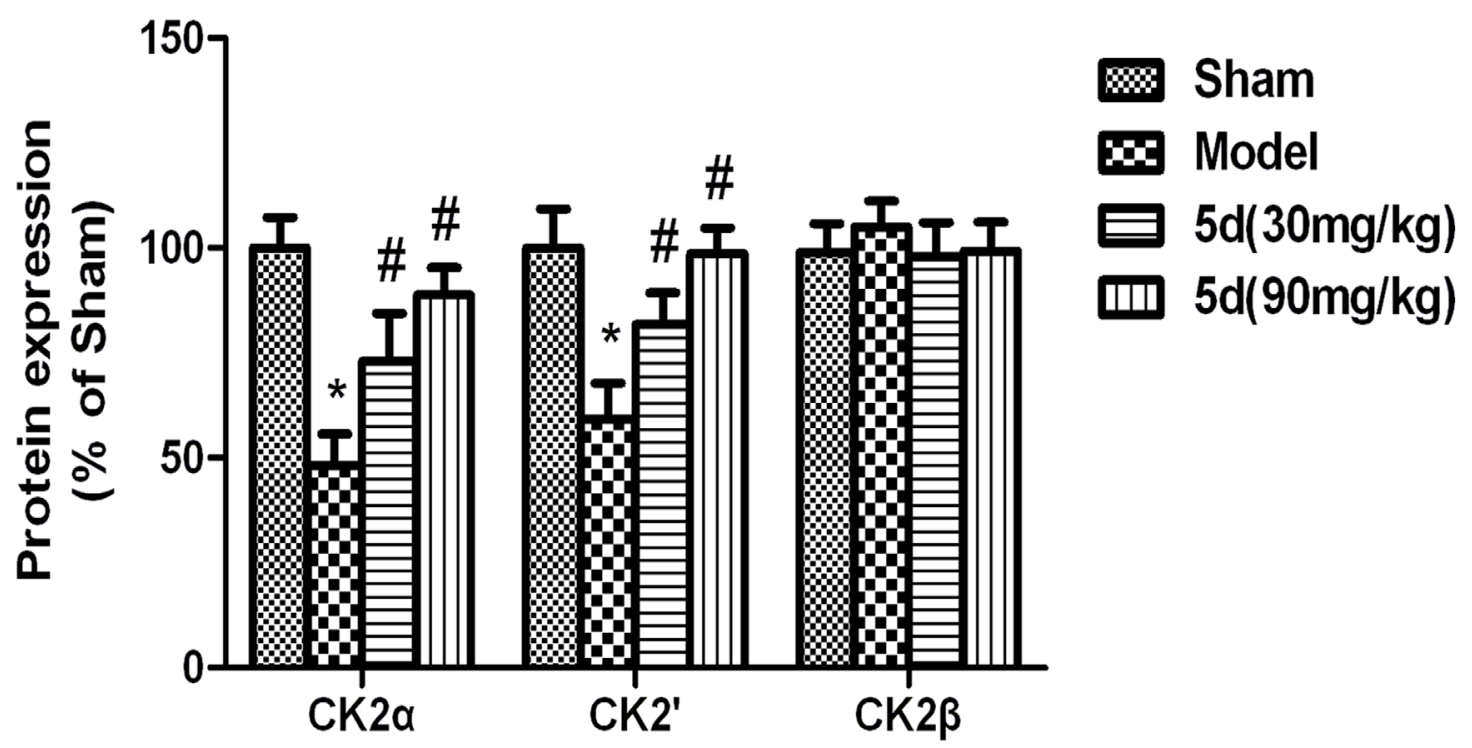

Figure 2: Effects of $5 d$ on CK2 $\alpha$, CK2 $\alpha$ 'and CK2 $\beta$ protein levels in the brains of rats after I/R. A. Representative Western blots of CK2 $\alpha$, CK $2 \alpha$ 'and CK2 $\beta$ protein levels in the brains of rats. B. CK2 $\alpha$, CK2 $\alpha$ 'and CK2 $\beta$ proteins expression were normalized to b-actin level. Data are expressed as means $\pm \mathrm{SD}(n=4) .{ }^{*} P<0.05$ vs Sham group. ${ }^{\sharp} P<0.05$ vs Model group. 
5d blocked the translocation of p47phox and Rac1 from cytoplasm to membrane

It is known that NADPH oxidase activation can be initiated when the cytosolic subunits GTP-Rac1, p67phox, and $\mathrm{p} 47 \mathrm{phox}$ are translocated to the membrane to form the NADPH oxidase complex. Therefore, to detect the degree of translocation of p47phox, p67phox, and Rac1, brain tissues of rats were separated into cytosolic and membrane fractions and then assayed by Western blot with these subunits' antibodies. As shown in Figure $7 \mathrm{~A}$ and $7 \mathrm{~B}$, the levels of Rac1 and $\mathrm{p} 47$ phox protein expression were profoundly decreased in the membrane fractions from 5 d-treated brains compared with that from vehicle-treated brains under I/R conditions. Besides, by immunoprecipitation with the GST-PAK1 PBD beads, 5d induced an obvious decrease in Rac1 activity under I/R conditions compared with the Sham group (Figure 7C).The results above indicated that $5 \mathrm{~d}$ prevented the translocation of subunits from cytoplasm to the membrane after $\mathrm{I} / \mathrm{R}$. However, the levels of $\mathrm{p} 67 \mathrm{phox}$ protein expression in the membrane fractions was not obviously changed after I/R (data not shown).

A

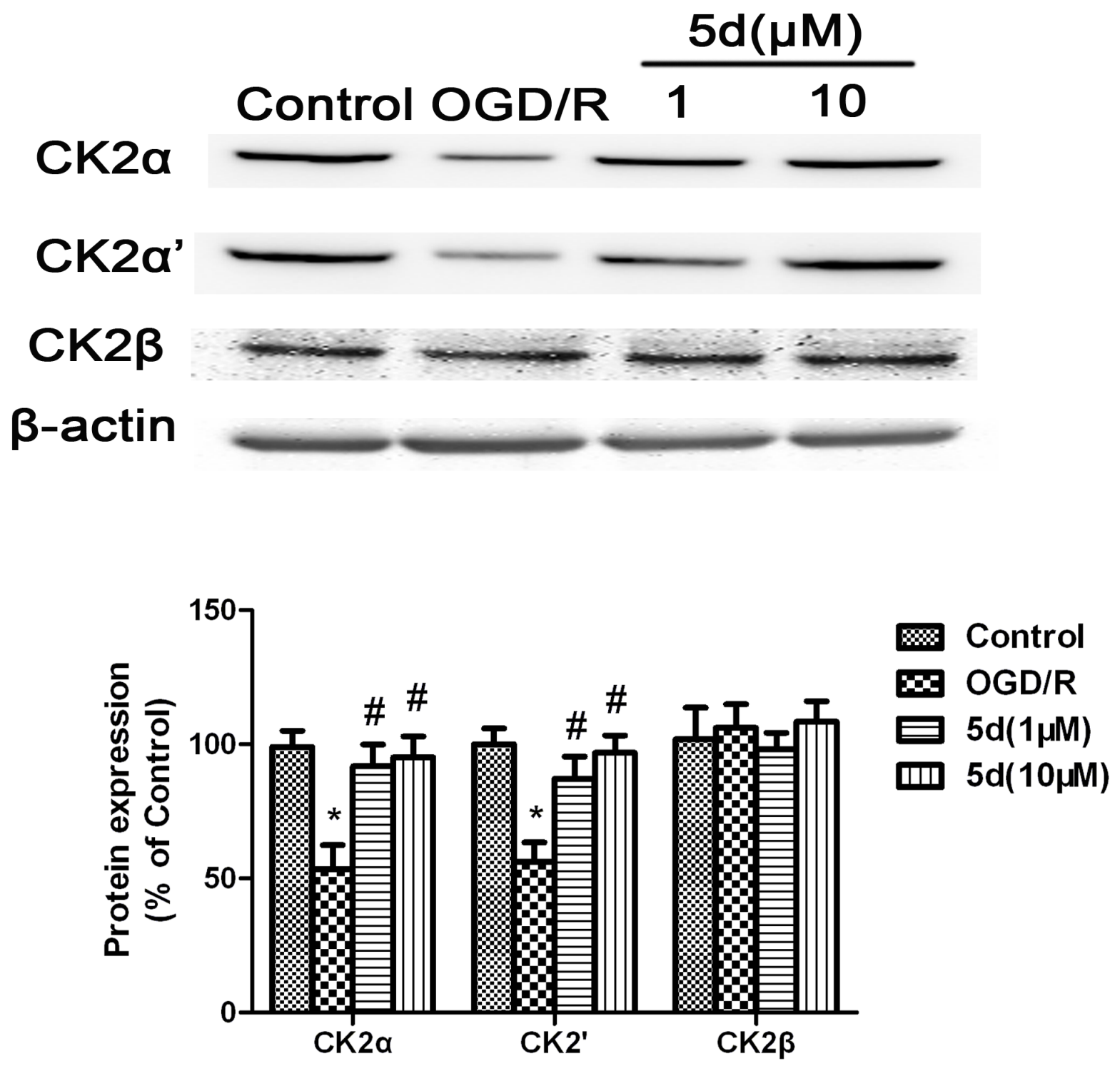

Figure 3: Effects of 5d on CK2 $\alpha$, CK2 $\alpha$ 'and CK2 $\beta$ protein levels in cortical neurons after OGD/R. A. Representative Western blots of CK $2 \alpha, \mathrm{CK} 2 \alpha$ ' and CK2 $\beta$ protein levels in cortical neurons. B. CK2 $\alpha, \mathrm{CK} 2 \alpha$ ' and CK2 $\beta$ proteins expression were normalized to b-actin level. Data are expressed as means $\pm \mathrm{SD}(n=4) .{ }^{*} P<0.05$ vs Control group. ${ }^{*} P<0.05$ vs $\mathrm{OGD} / \mathrm{R}$ group. 
$5 d$ inhibited the dissociation of CK2 $\alpha$ and Rac1

To explore how the loss of CK2 activity induced by I/R promotes the activation of NADPH oxidase via translocation of Rac1 and p47phox in cerebral ischemia, we examined the possibly physical interactions between CK2 $\alpha$ and p 47 phox or between CK2 $\alpha$ and Rac1. Figure $8 \mathrm{~A}$ and $8 \mathrm{~B}$ showed that there existed an interaction between CK2 $\alpha$ and Rac1 under normal conditions, which was disrupted after I/R injury. $5 \mathrm{~d}$ blocked the dissociation of CK $2 \alpha$ and Rac 1 after I/R. To verify the specificity of the CK2 $\alpha$ antibody applied in the co-IP assay, the samples of Sham group was immunoprecipitated with normal IgG as a negative control. The results showed that there were no interacting bands between CK2 $\alpha$ and Rac1. Furthermore, to confirm the direct interaction between CK2 $\alpha$ and Rac1, an immunofluorescent method was applied. As shown in Figure 8B, CK2 $\alpha$ immunopositive cells in the brains of Sham group were mainly colocalized with the Rac1

A

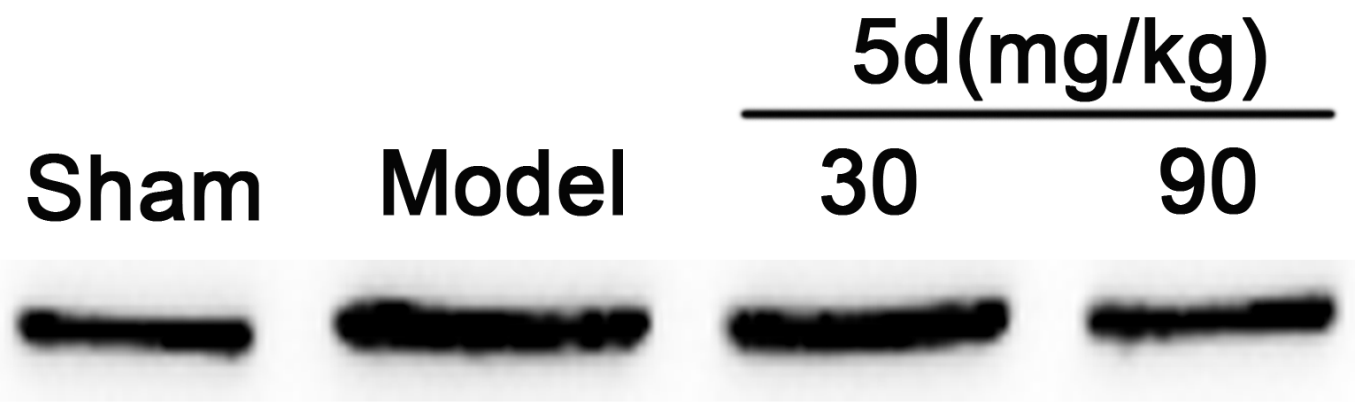

\section{$\beta$-actin}

B

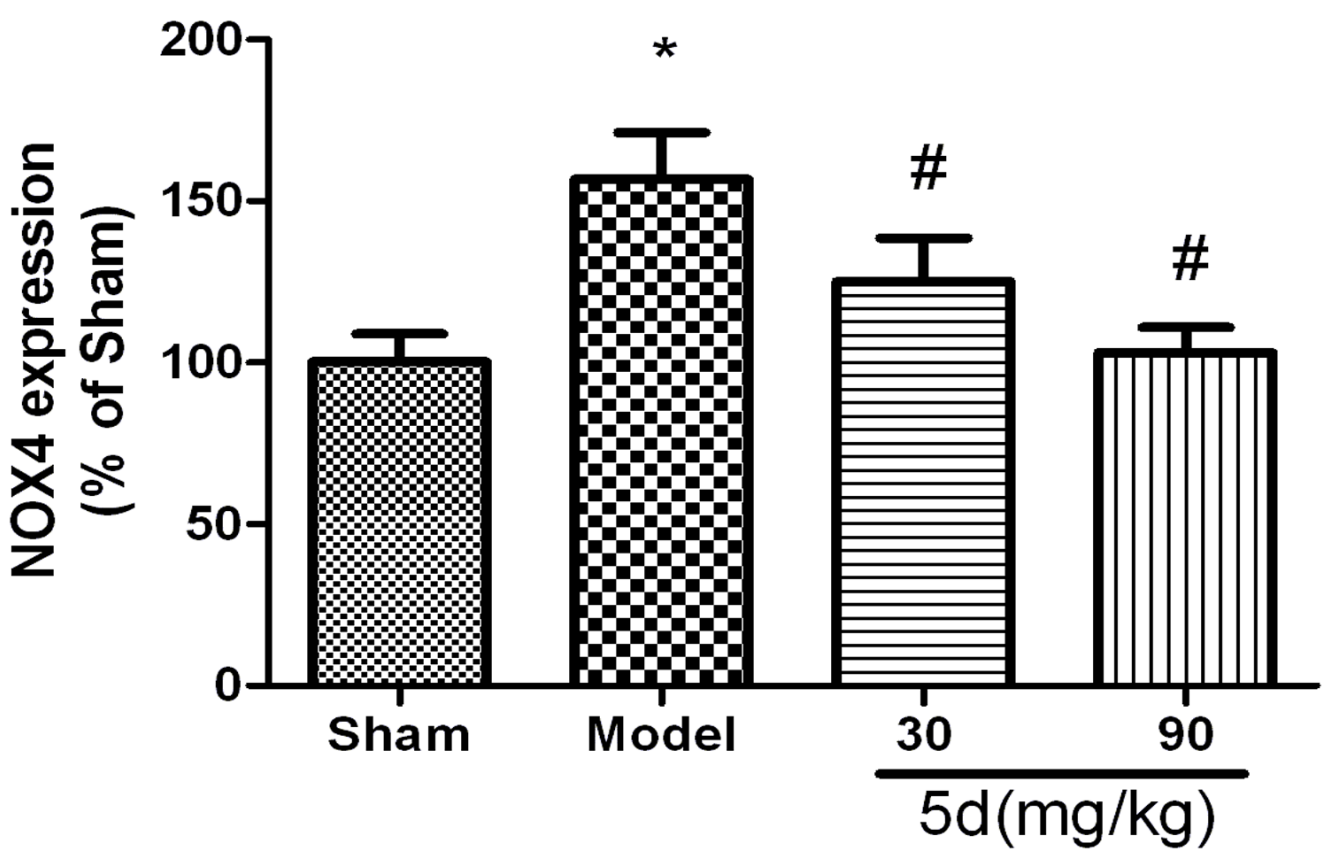

Figure 4: Effects of 5d on NOX4 protein level in the brains of rats after I/R. A. Representative Western blots of NOX4 protein level in the brains of rats. B. NOX4 protein expression were normalized to b-actin level. Data are expressed as means \pm SD $(n=4)$. ${ }^{*} P<$ 0.05 vs Sham group. ${ }^{\#} P<0.05$ vs Model group. 
immunopositive cells, whereas the coimmunoreactive cells were obviously diminished under I/R conditions (Figure $8 \mathrm{~B}$ ). These data indicate that after I/R injury, the direct interaction between Rac1 and CK $2 \alpha$ is broken, Rac1 releases from $\mathrm{CK} 2 \alpha$ and translocates to membrane. Our results found that $5 \mathrm{~d}$ treatment reversed this process by protecting the interaction between CK $2 \alpha$ and Rac1 from damage induced by $\mathrm{I} / \mathrm{R}$, and blocking the translocation of Rac1 to the membrane. 5d suppressed ROS production through upregulation of CK2 activity after $\mathbf{I} / \mathbf{R}$

In order to quantify the levels of ROS production, we evaluated the expression of 3-nitrotyrosine (3-NT) protein by Western blot in vivo and in vitro. As shown in Figure 9A and 9B, in comparison with the vehicle-treated brains, the level of 3-NT protein expression was markedly

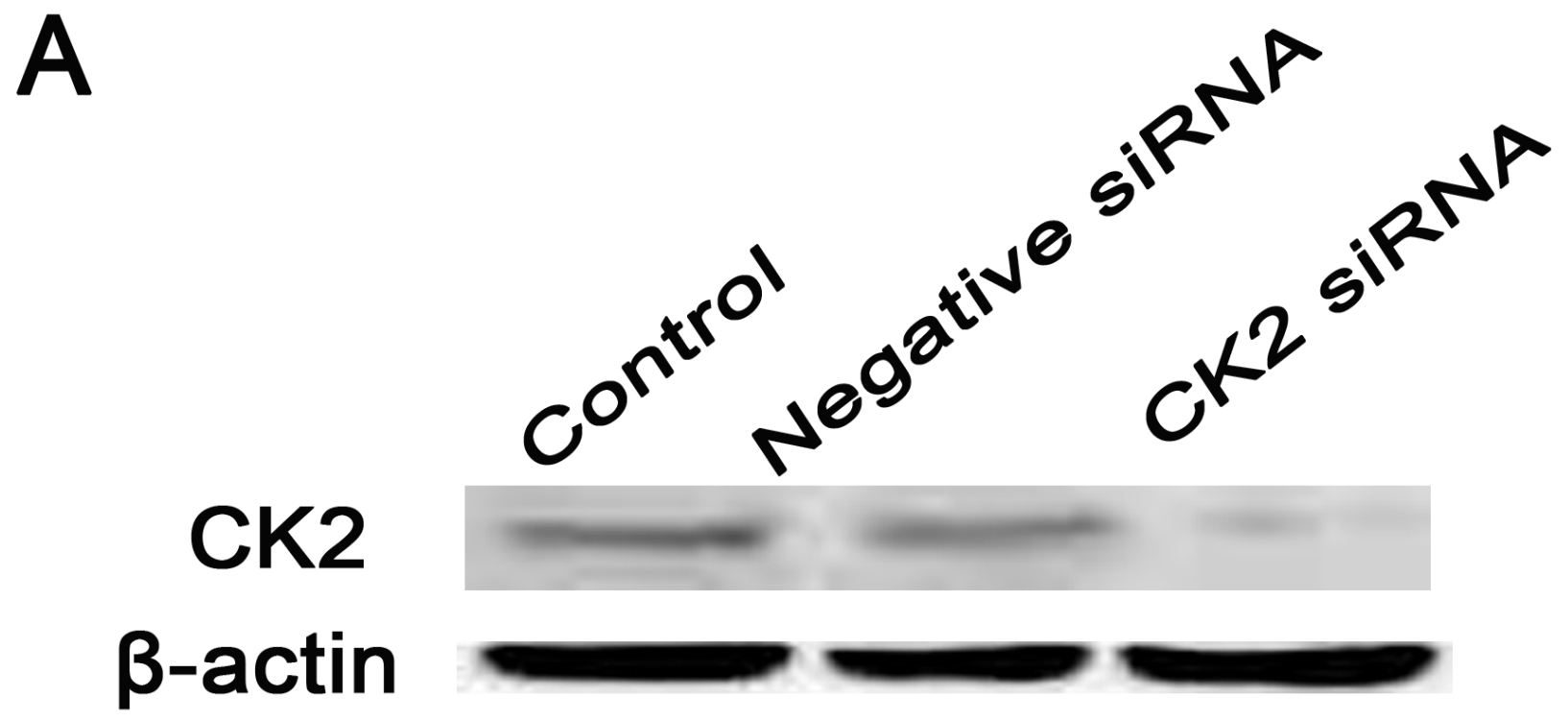

B

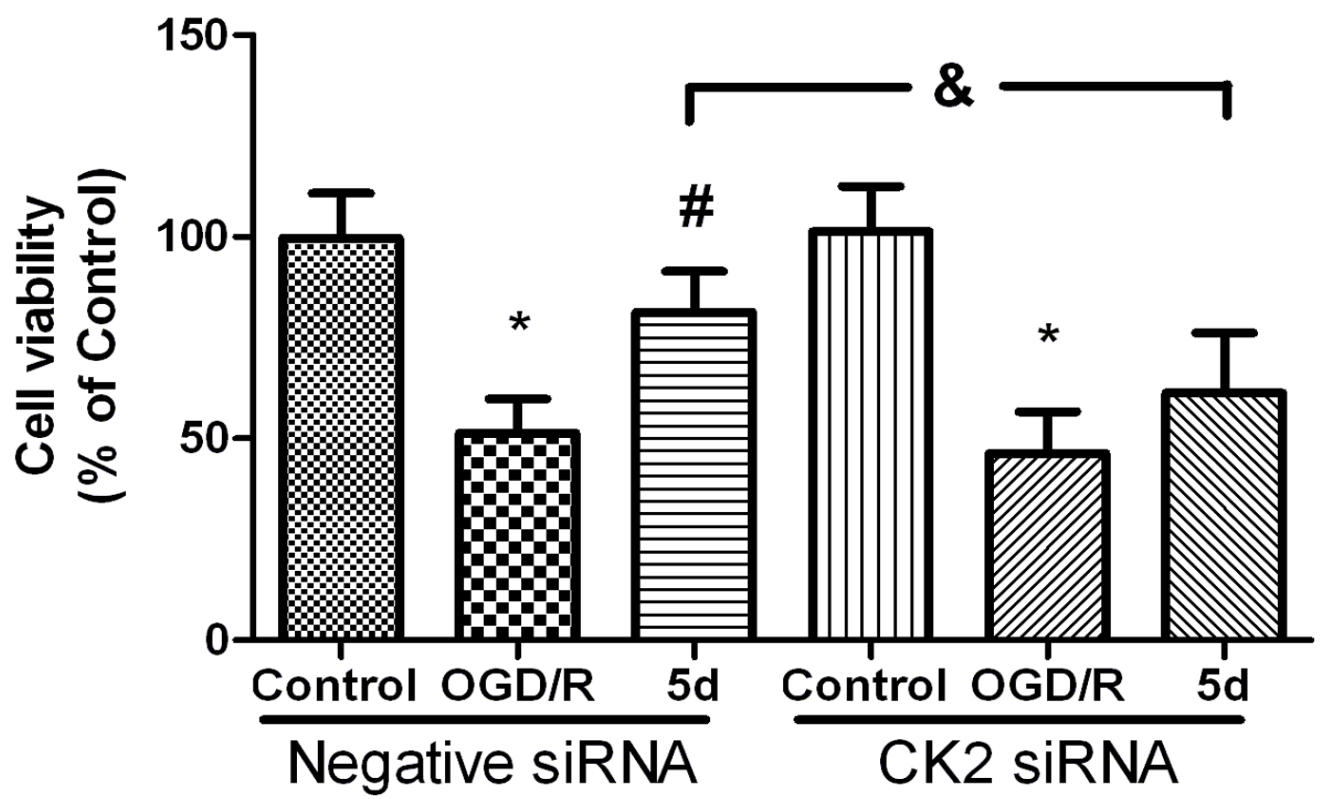

Figure 5: 5d increased the neuronal viability through up-regulation of CK2 expression. A. Cortical neurons were transfected with Negative siRNA or CK2 siRNA for $24 \mathrm{~h}$, and then cells were harvested to detect CK2 protein expression by Western blot. B. Cortical neurons were transfected with siCK2 or Negative siRNA for $24 \mathrm{~h}$. The transfected cells were treated with $5 \mathrm{~d}$ for $24 \mathrm{~h}$ before OGD/R treatment. Cell viability was measured by MTT assay. Data are expressed as means $\pm \mathrm{SD}(n=4) .{ }^{*} P<0.05 v s$. Control group, ${ }^{\#} P<0.05$ vs. OGD/R group. 
enhanced in the brains of Model group. 5d notably decreased 3-NT protein expression after I/R injury. In consistence with the in vivo results, in vitro experiment indicated that $5 \mathrm{~d}$ profoundly suppressed the elevation of 3-NT protein expression induced by I/R injury (Figure 9C and 9D). Furthermore, in comparison with scrambledsiRNA-transfected or untransfected samples, CK2 $\alpha$ specific siRNA transfection for $48 \mathrm{~h}$ in the cortical neurons after OGD/R prominently abolished 5d-induced downregulation of 3-NT protein expression (Figure 10). These data suggest that $5 \mathrm{~d}$ inhibits ROS production through elevating CK2 activity during I/R.

\section{DISCUSSION}

Ischemic stroke has been demonstrated to be triggered by an imbalance of antioxidant defense system and oxidative stress. Thus, use of antioxidants might possibly limit oxidative damage so as to ameliorate disease progression [20-22]. We recently reported the free radical scavenging potential of $5 \mathrm{~d}$, coupled with the neuroprotective effect on cerebral ischemia [9]. However, further study is required to elucidate the possible mechanism(s) of $5 \mathrm{~d}$ against ischemic stroke. In the present study, we provided evidence demonstrating that after I/R injury, 5d decreased NADPH oxidase activity through the positive regulation of CK2.

A
NOX4
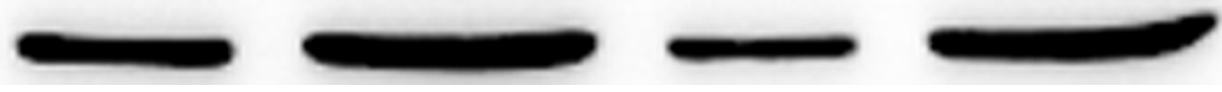
$\beta$-actin

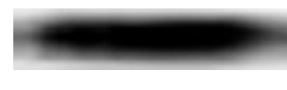

B

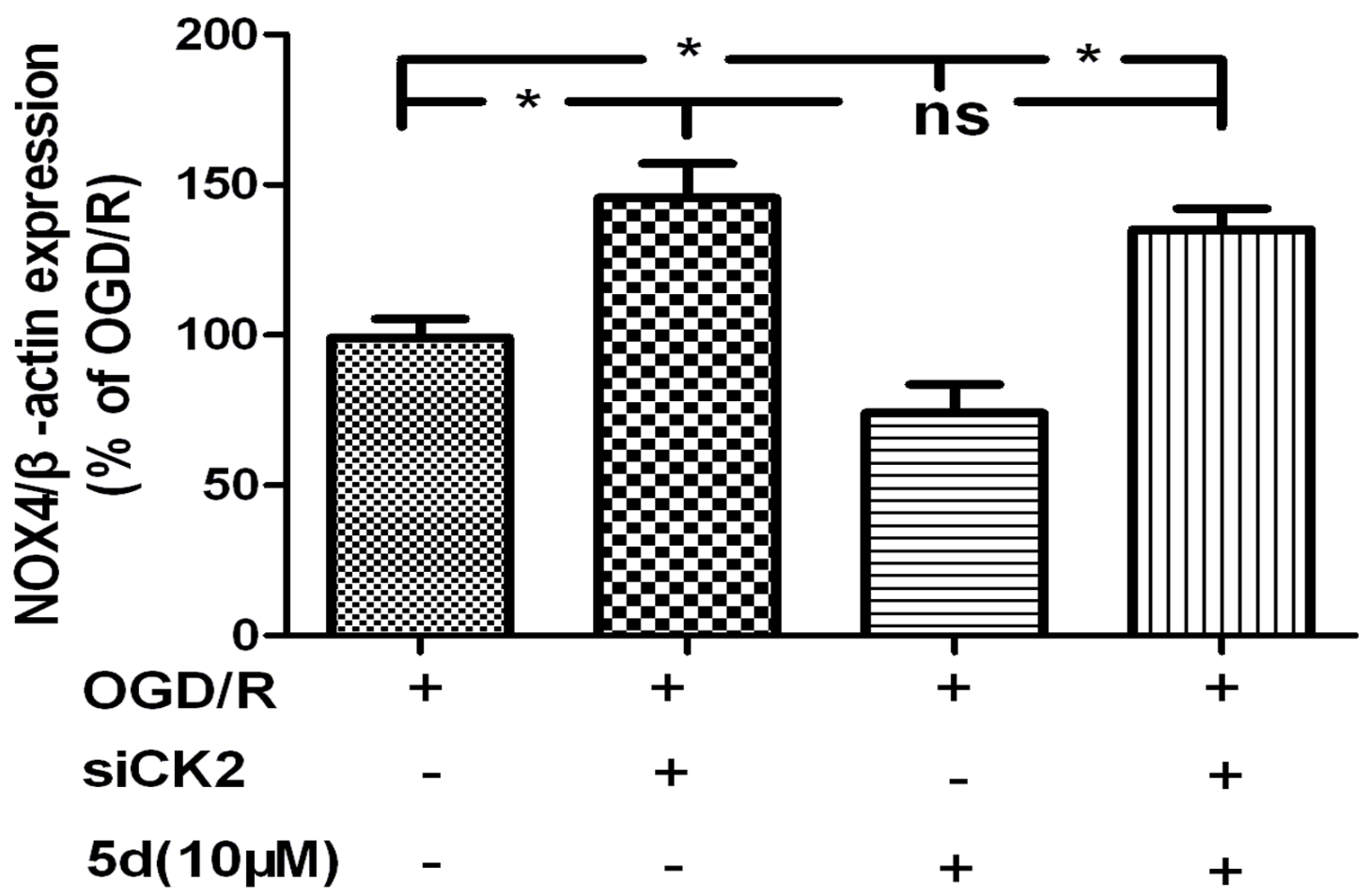

Figure 6: CK2 negatively modulates the expression of NOX4 protein. A. Cortical neurons were transfected with siCK2 for 24 $\mathrm{h}$. The transfected cells were treated with $5 \mathrm{~d}$ for $24 \mathrm{~h}$ before OGD/R and the expression of NOX4 protein was examined by Western blot. B. Statistical results from the densitometric measurements after normalization against b-actin were calculated as the means \pm SD $(n=4)$. Values are expressed as a percentage of the corresponding OGD/R value. ${ }^{*} p<0.05$; ns, nonsignificant. 
Protein kinase CK2 is a serine/threonine kinase comprised of $\alpha, \alpha^{\prime}$ and $\beta$, of which $\alpha$ and $\alpha^{\prime}$ are catalytic subunits, and $\beta$ is a regulatory subunit $[23,24]$. There is literature demonstrating the neuroprotection of $\mathrm{CK} 2$ after ischemia stroke $[15,18,19]$. In line with previous studies, our results showed that CK2 activity together with CK $2 \alpha$ and $2 \alpha^{\prime}$ protein expression were significantly down-regulated after I/R injury. Interestingly, $5 \mathrm{~d}$ treatment obviously increased CK2 activity as well as CK2 $\alpha$ and $2 \alpha$ ' protein levels after $\mathrm{I} / \mathrm{R}$.

The NADPH oxidase family of enzymes, also called NOXs, produce ROS as their primary function. Consequently, their roles in tightly regulated redox signaling pathways are areas of intense study $[25,26]$. The activation of NADPH oxidase is initiated by translocation of Rac1, p67phox, and p47phox from cytoplasm to the membrane $[13,27]$. In an HL-60 cell line, Park and his co-workers found that CK2 can phosphorylate p47phox, as well as CK2 inhibition by DRB can facilitate translocation of p47phox [28]. Along with these lines, we demonstrated in our study that $5 \mathrm{~d}$-induced increase of CK2 activity blocked the translocation of cytosolic Rac1 and p47phox to the membrane. Meanwhile, the level of NOX4 protein expression, the most widely distributed isoform of NADPH oxidase subunits (NOXs), was obviously declined in the brains of $5 \mathrm{~d}$-treated rats. However, CK2specific siRNA impaired 5d's inhibitory effect on NOX4 protein expression. Of note, we found that I/R injury
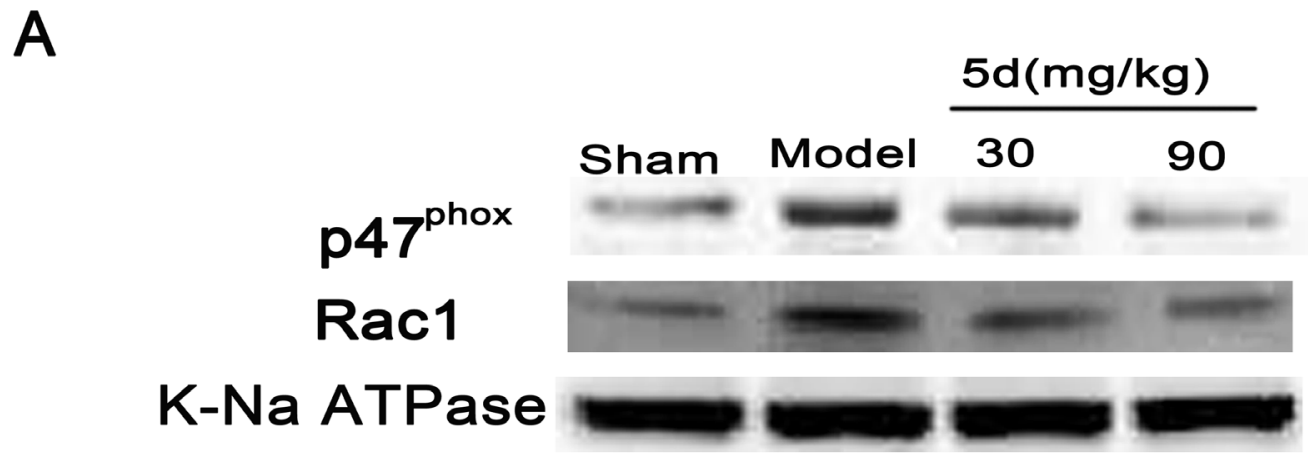

B
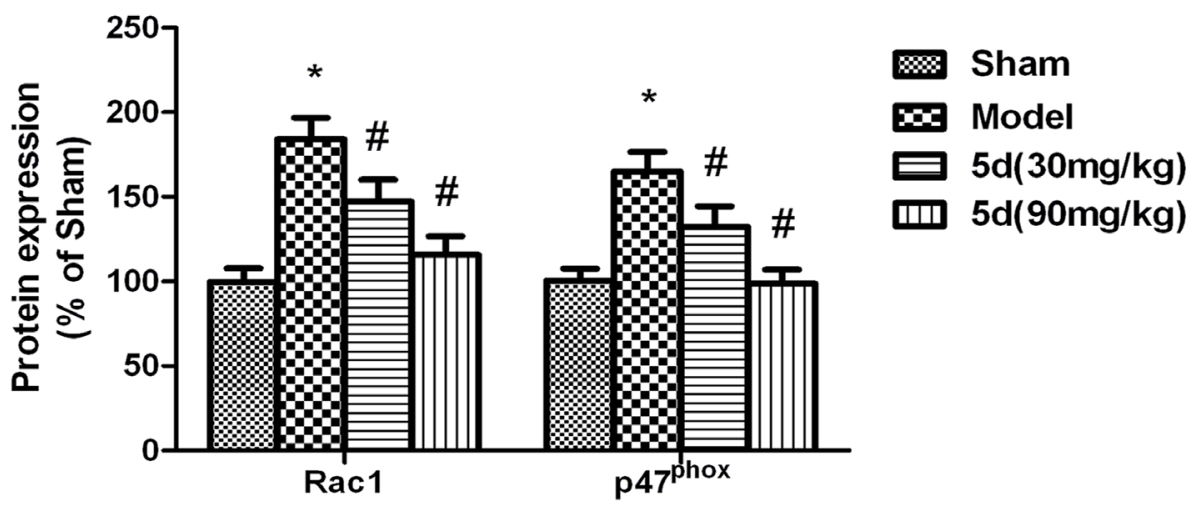

\section{GTPYS GDP Sham Model $5 d$}

\section{IP: GST-PAK1 PBD WB:Anti-Rac1}

\section{Lysate WB: Anti-Rac1}

Figure 7: Effects of 5d on the translocation of cytosolic p47phox and Rac1 to membrane. A. Representative Western blots of p47phox and Rac1 protein expression in membrane fractions from the brains of rats. K-Na ATPase antibody was applied as a membrane marker. B. The expression of p47phox and Rac1 protein in the membrane were normalized to K-Na ATPase level. C. Rac1 activity was measured by co-IP using GST-PAK1 PBD, followed by Western blots with a Rac1 antibody ( $n=6$ per group).Data are expressed as means $\pm \mathrm{SD}(n=4) .{ }^{*} P<0.05$ vs Sham group. ${ }^{\#} P<0.05$ vs Model group. 
A

$\frac{\text { IgG }}{\text { Sham }}$

B

Anti-Rac1 Anti-CK2 $\alpha$
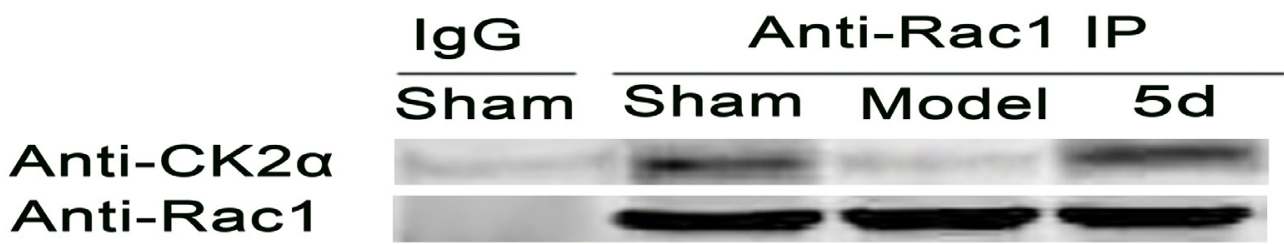

C

CK2a

Rac1
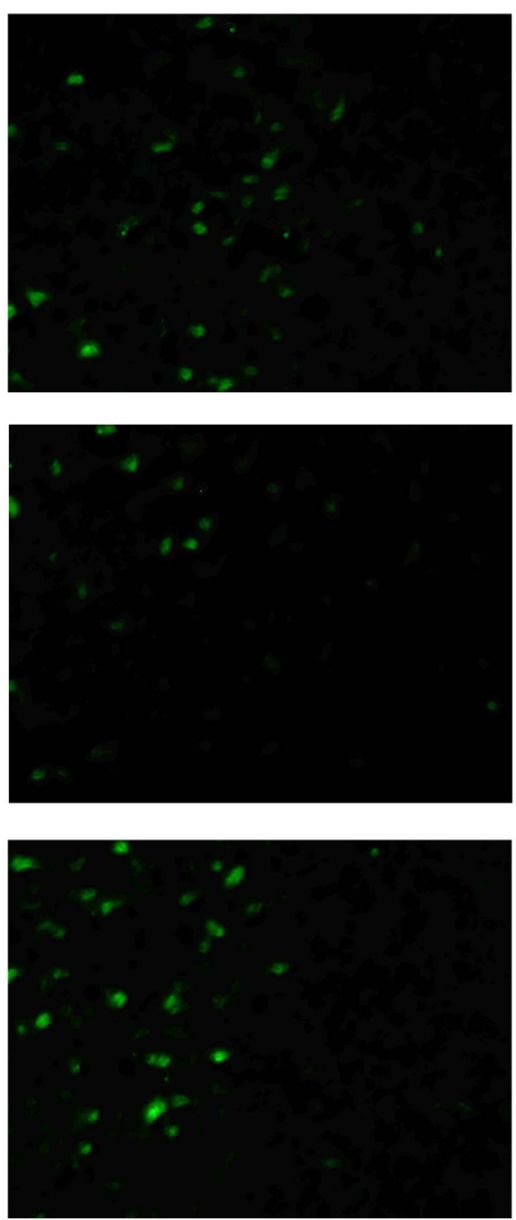

CK2 $\alpha /$ Rac1
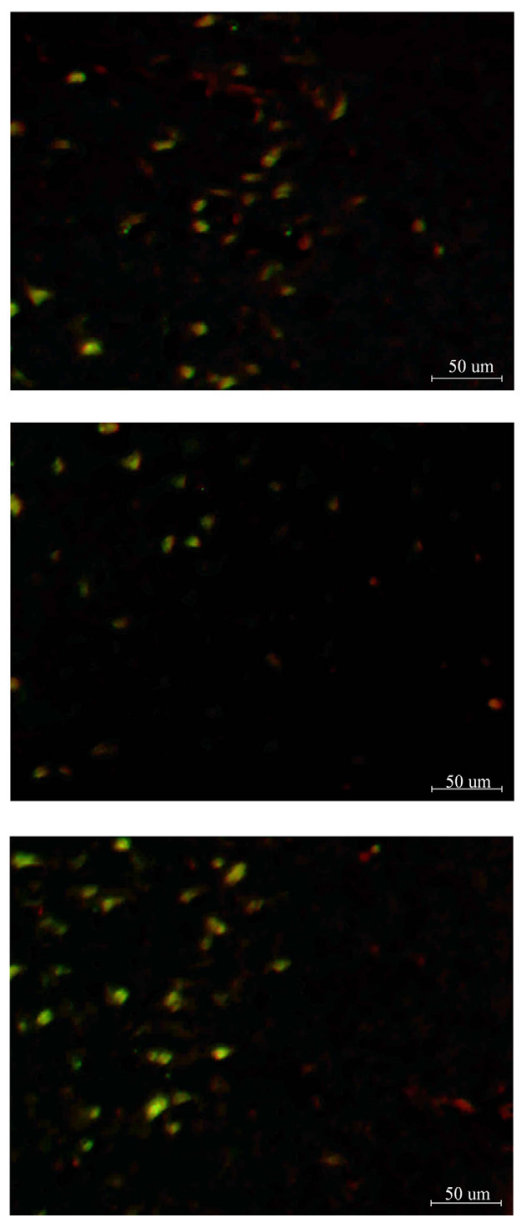

Figure 8: Effects of 5d on the relationship between CK2 and Rac1 protein levels. Brain tissue lysates of the Sham or Mode group were immunoprecipitated with an anti-CK2 $\alpha$ antibody A. or an anti-Rac1 antibody B. followed by Western blots with an anti-Rac1 antibody and an anti-CK2 $\alpha$ antibody $(n=4)$. C. Double labeling with an anti-CK2 $\alpha$ antibody and an anti-Rac1 antibody using tissue lysates from brains of the Sham or Mode group ( $n=6$ per group). 
promoted the dissociation between $\mathrm{CK} 2 \alpha$ and Rac1, which could be suppressed after $5 \mathrm{~d}$ administration. These findings indicate that $5 \mathrm{~d}$ could prevent the dissociation between CK2 $\alpha$ and Rac1 so as to block NADPH oxidase activation after $\mathrm{I} / \mathrm{R}$.

In the present study, it was also demonstrated that $5 \mathrm{~d}$ strongly depressed I/R- or OGD/R-induced ROS generation evidenced by the down-regulation of 3-NT protein expression. Blocking $\mathrm{CK} 2 \alpha$ protein expression by $\mathrm{CK} 2$ siRNA in primary cortical neurons weakened the inhibitory effect of $5 \mathrm{~d}$ on 3 -NT protein expression. Thus, we suggest that $5 \mathrm{~d}$ exhibits neuroprotective effect against the $\mathrm{I} / \mathrm{R}$ or $\mathrm{OGD} / \mathrm{R}$ injury via inhibiting ROS generation induced by NADPH oxidase activation through the elevation of CK2 activity.

Taken together, our data revealed the mechanism underlying 5d's neuroprotection on cerebral ischemia. This occurs via an increase of CK2 activity, which obstructs I/R-induced dissociation between CK2 $\alpha$ and Rac1, decreases NADPH oxidase activtiy, inhibits ROS production and finally realizes the protective effect of $I / R$. Despite the current results, further research is needed to exploit the remaining potential of $5 \mathrm{~d}$ in cerebral ischemia. Following studies in our laboratory will focus on whether $5 \mathrm{~d}$ could induce a late phase neuroprotection, diffuse across biological membrane and blood-brain barrier, affect mitochondrial function as well as the relevant mechanisms involved.

\section{MATERIALS AND METHODS}

\section{Chemicals and reagents}

5d, which purity > 99\%, was synthesized by the Center of Drug Discovery, China Pharmaceutical University. Its molecular structure was shown in previous studies [9, 29] and was dissolved in normal saline. Membrane and cytosol protein extraction kit and Lactate dehydrogenase (LDH) kit were obtained from Beyotime Institute of Biotechnology (Haimen, China). Rac1 activation assay kit was purchased from Millipore Corporation (MA, USA). The primary antibodies used were polyclonal antibodies against $\mathrm{CK} 2 \alpha, \mathrm{CK} 2 \alpha$, CK2 $\beta$, NOX4, Rac1, p47phox ${ }^{\text {p }} 7^{\text {phox }}, \beta$-actin (Millipore Corporation, MA, USA). The goat anti-rabbit IgG-HRP secondary antibody was supplied by Bioworld Technology Inc. (MN, USA). NBP, MTT (3-(4,5-Dimethylthiazol2-yl)-2,5-diphenyltetrazolium bromide), and all other
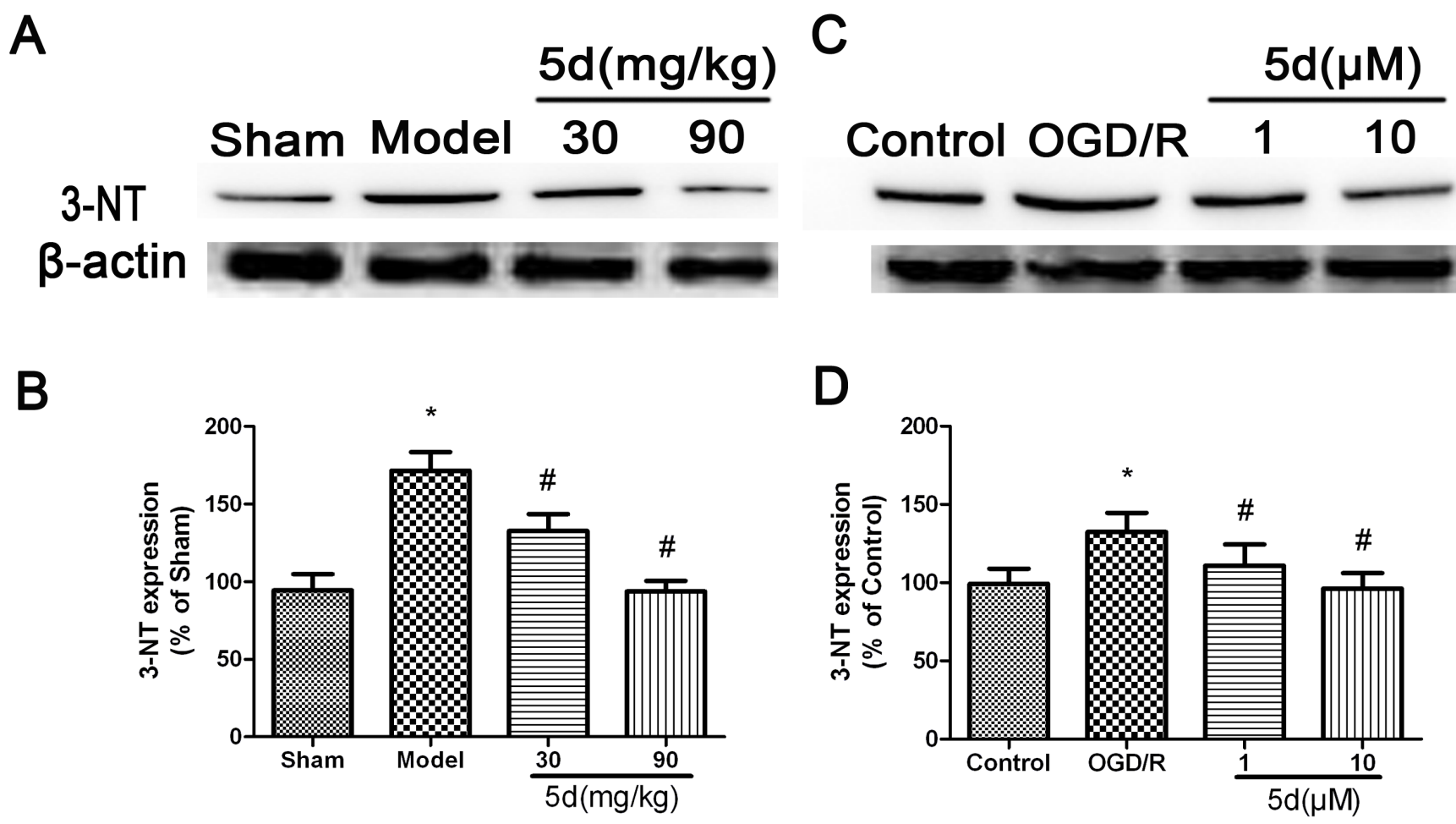

Figure 9: Effects of 5d on 3-NT protein expression in the brains of rats after I/R and in cortical neurons after OGD/R. A. Representative Western blots of 3-NT protein expression in the brains of rats. B. 3-NT protein expression in the brains of rats were normalized to b-actin level. C. Representative Western blots of 3-NT protein expression in cortical neurons after OGD/R. D. 3-NT protein expression in cortical neurons were normalized to b-actin level. Data are expressed as means $\pm \operatorname{SD}(n=4)$. ${ }^{*} P<0.05 v s$ Sham group or Control group. ${ }^{\#} P<0.05$ vs Model group or OGD/R group. 
A

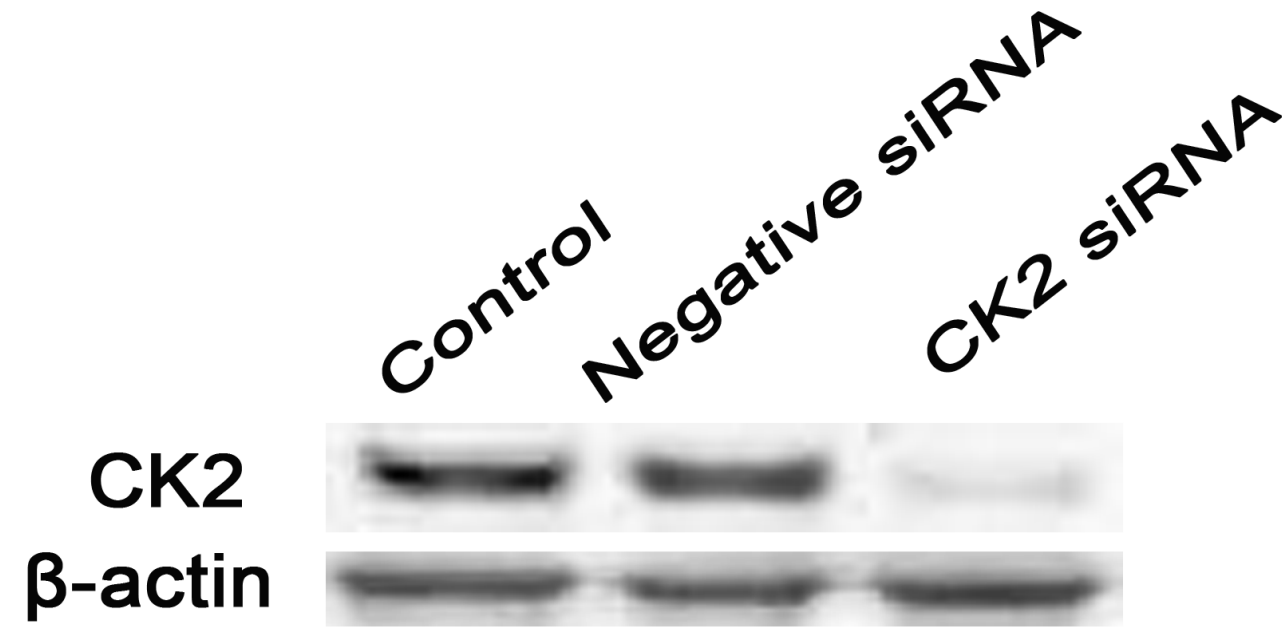

B

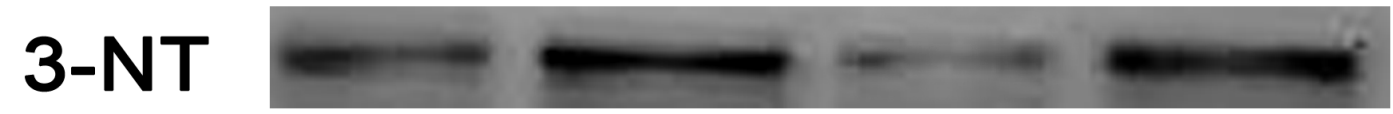

\section{$\beta$-actin}

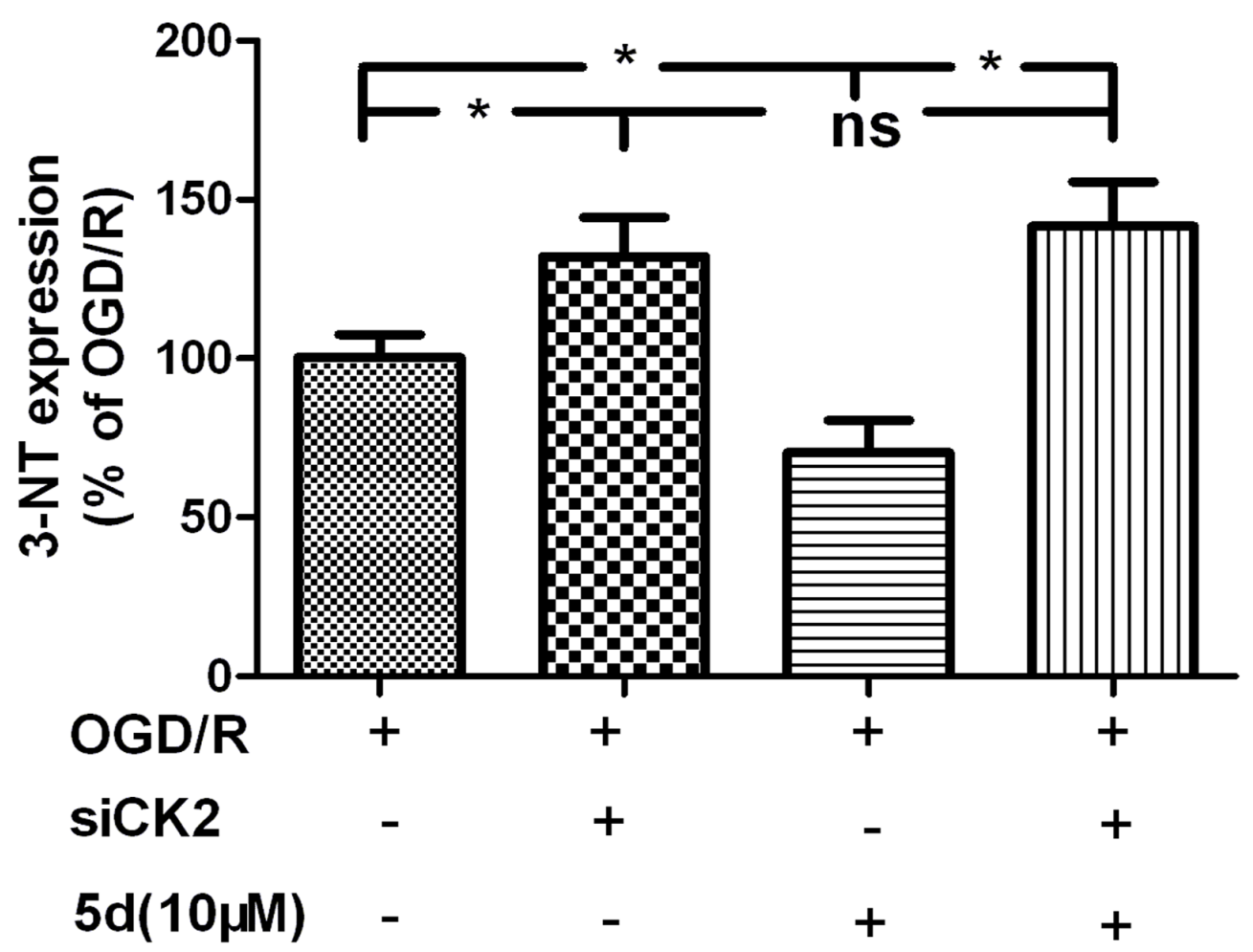

Figure 10: CK2 negatively modulate the expression of 3-NT protein. A. Cortical neurons were transfected with Negative siRNA or CK2 siRNA for $24 \mathrm{~h}$, and then cells were harvested to detect CK2 protein expression by Western blots. B. Cortical neurons were transfected with siCK2 for $24 \mathrm{~h}$. The transfected cells were treated with $5 \mathrm{~d}$ for $24 \mathrm{~h}$ before OGD/R and the expression of 3-NT protein was examined by Western blot. C. Statistical results from the densitometric measurements after normalization against b-actin were calculated as the means $\pm \mathrm{SD}(n=4)$. Values are expressed as a percentage of the corresponding OGD/R value. ${ }^{*} P<0.05 ; \mathrm{ns}$, nonsignificant. 
chemicals were purchased from Sigma Chemical Co., (St. Louis, MO, USA).

\section{Animals}

Adult male Sprague-Dawley rats (SD) weighing 250 300 g were purchased from B\&K Universal Group Limited (Shanghai, China). The rats were kept under standard laboratory conditions with light from 08:00 a.m. to 08:00 p.m. Animals were free access to food and water. Animals care and treatment in this study observed the National Institute of Health Guidelines for the Care and Use of Laboratory Animals. All procedures were conducted in accordance with the Institutional Animal Care and Utilization Committee of China Pharmaceutical University.

\section{Middle cerebral artery occlusion (MCAO) and drug administration}

After anesthetized i.p. with $350 \mathrm{mg} / \mathrm{kg}$ chloral hydrate (Sinopharm Chemical Reagent, Beijing, China), all rats were subjected to the middle cerebral artery occlusion (MCAO), a procedure described previously [9]. During the experiment, the cerebral blood flow (CBF) was monitored by laser Doppler flowmetry (LDF 100C, BIOPAC Systems) to ensure that occlusion of the MCA with the specific suture resulted in $>80 \%$ decline in $\mathrm{CBF}$ [30]. The control group received a sham surgery. The core body temperature of individual animals was monitored with a rectal probe and maintained at $37 \pm 0.5^{\circ} \mathrm{C}$ during the whole procedure.

All rats were divided randomly into four groups as following: (1) Sham group, (2) Model group, (3) I/R + 5d (30 mg/kg, i.g.) group, (4) I/R + 5d (90 mg/kg, i.g.) group. The compound of $5 \mathrm{~d}$ was administered daily, starting at the onset of reperfusion and continued for 3 days.

\section{Coimmunoprecipitation (co-IP) assay}

At $3 \mathrm{~d}$ after reperfusion, brains were isolated and lysed on ice using lysis buffer, which contains $25 \mathrm{mM}$ HEPES ( $\mathrm{pH}$ 7.7), $0.4 \mathrm{M} \mathrm{NaCl}, 1.5 \mathrm{mM} \mathrm{MgCl}_{2}, 2 \mathrm{mM}$ EDTA, 1\% Triton X-100, $0.5 \mathrm{mM}$ DTT, and protease inhibitor cocktail (Sigma-Aldrich). The brain tissue lysates were incubated with the $\mathrm{CK} 2 \alpha$ or Rac1 antibody overnight, then coupled to the immobilized protein $A / G$ agarose beads (Beyotime Institute of Biotechnology, Haimen, China) at $4^{\circ} \mathrm{C}$ for $4 \mathrm{~h}$. After extensive washing for three times in lysis buffer (a 4-fold lower concentration of $\mathrm{NaCl}$ than the original lysis buffer), coimmunoprecipitated Rac1 or CK2 $\alpha$ was detected by Western blot with Rac1 or CK2 $\alpha$ antibodies. Normal IgG was purchased from Santa Cruz Biotechnology using as a negative control.

\section{Immunofluorescent staining}

At $3 \mathrm{~d}$ after reperfusion, the rats were perfused with heparinized $(10 \mathrm{U} / \mathrm{ml})$ saline and then with $4 \%$ formaldehyde in phosphate buffered salin (PBS). The brain tissues were sectioned at $50 \mu \mathrm{m}$ using a vibratome and stored at $-20^{\circ} \mathrm{C}$. The sections were washed three times with PBS, blocked with 5\% bovine serum albumin $(0.3 \%$ Triton X-100 in PBS) for $1 \mathrm{~h}$ and incubated overnight in primary antibodies. The primary antibodies used in this experiment were rabbit anti-CK2 $\alpha$ (1:100; Millipore) and mouse anti-Rac1 (1:100; Millipore). The sections were washed three times with PBS and then incubated for 60 min with Alexa Fluor 488-conjugated goat anti-mouse IgG and Alexa Fluor 594-conjugated goat anti-rabbit IgG. Sections were rinsed three times with PBS, mounted on glass slides and covered with mounting medium containing DAPI (Beyotime Institute of Biotechnology, Haimen, China).

\section{Rac1 activation assay}

At $3 \mathrm{~d}$ after reperfusion, brains were isolated and lysed with $\mathrm{Mg}^{2+}$ lysis buffer according to the manufacturer's instruction (Millipore). Briefly, brain tissue lysates $(1 \mathrm{mg} / 500 \mu \mathrm{l})$ were incubated with a $\mathrm{Rac} / \mathrm{cdc} 42$ assay reagent (PAK1-PBD, agarose) at $4^{\circ} \mathrm{C}$ for $1 \mathrm{~h}$. The pellets were collected by centrifugation at 14,000 $\mathrm{g}$ for 5 $\mathrm{s}$, washed in lysis buffer, and resuspended in $40 \mu \mathrm{l}$ of $2 \times$ Laemmli buffer. Samples were incubated for $15 \mathrm{~min}$ at $30^{\circ} \mathrm{C}$ with GTP $\gamma \mathrm{S}$ as a positive control, while guanosine diphosphate as a negative control. Finally, co-IP was performed with Rac/cdc42 assay reagent (PAK1-PBD, agarose).

\section{Primary cortical neuron culture}

Primary cortical neurons were prepared from E17 SD rats and the cortices were isolated and cultured as described by Ling et al., 2015 [31].

\section{Oxygen-glucose deprivation and recovery $(\mathrm{OGD} / \mathrm{R})$ treatment}

The OGD/R treatment was conducted according to our previous studies [31].

\section{Cell viability assessment}

At $24 \mathrm{~h}$ post-OGD, neuronal cell death was measured by the MTT assay and lactate dehydrogenase (LDH) activity in the medium was determined in accordance with our previous studies [31]. 


\section{Transient transfection of small RNA interference (siRNA)}

The transient transfection of siRNA was performed as described by Ling et al., 2015 [31]. The siRNA construct used was obtained as mismatched siRNA control (Negative Control, Santa Cruz Biotechnology, Santa Cruz, CA) and siRNA against CK2 (siCK2, Santa Cruz Biotechnology, Santa Cruz, CA).

\section{Western blot analysis}

The western blot analysis was conducted according to our previous studies [31].

\section{Statistical analysis}

All data are expressed as mean \pm SD. Statistical analyses were performed with one-way ANOVA followed by Turkey's post hoc test for multiple comparison tests. Significant differences were accepted when $p<0.05$.

\section{ACKNOWLEDGMENTS}

The authors express thanks to the staff of the Clinical Laboratory (Wuxi People's Hospital affiliated to Nanjing Medical University) for their technical assistance, and the reviewers for their comments and suggestions that improved this paper. This work was supported by the National Natural Science Foundation of China (grant 81503076 and 81373419).

\section{CONFLICTS OF INTEREST}

The authors declare no competing financial interests in this study.

\section{REFERENCES}

1. Suslina ZA, Piradov MA, Domashenko MA. Stroke: the review of the problem (15 years after). Zh Nevrol Psikhiatr Im S S Korsakova. 2014; 114: 5-13.

2. Donnan GA, Fisher M, Macleod M, Davis SM. Stroke. Lancet. 2008; 371: 1612-23. doi: 10.1016/S01406736(08)60694-7.

3. Volpe M, Paneni F. Shooting vascular oxidative stress: new hopes for stroke patients? Eur Heart J. 2015; 36: 1573-5. doi: 10.1093/eurheartj/ehv175.

4. Halladin NL. Oxidative and inflammatory biomarkers of ischemia and reperfusion injuries. Dan Med J. 2015; 62: B5054.

5. Yamashita T, Sato T, Sakamoto K, Ishii H, Yamamoto J. The free-radical scavenger edaravone accelerates thrombolysis with alteplase in an experimental thrombosis model. Thromb Res. 2015; 135:1209-13. doi: 10.1016/j. thromres.2015.04.011.

6. Gröger M, Plesnila N. The neuroprotective effect of $17 \beta$-estradiol is independent of its antioxidative properties. Brain Res. 2014; 1589C: 61-7. doi: 10.1016/j. brainres.2014.08.029.

7. Zhang Y, Wang L, Li J, Wang X. 2-(1-hydroxypentyl)benzoate increases cerebral blood flow and reduces infarct volume in rat model of transient focal cerebral ischemia. $\mathrm{J}$ Pharmacol Exp Ther. 2006; 317: 973-9.

8. Zhu Y, Tan S. Observation of dl-3n-butylphthalide combined Edarovone treating patients with progressive cerebral infarction. Chinese Journal of Practical Nervous Diseases. 2010; 13: 10-2.

9. Wu J, Ling JJ, Wang XL, Li TT, Liu JC, Lai YS, Ji H, Peng S, Tian J, Zhang Y. Discovery of a Potential Anti-Ischemic Stroke Agent: 3-Pentylbenzo[c]thiophen-1(3H)-one. J Med Chem. 2012; 55: 7173-81. doi: 10.1021/jm300681r.

10. Landry WD, Cotter TG. ROS signalling, NADPH oxidases and cancer. Biochem Soc Trans. 2014; 42: 934-8. doi: 10.1042/BST20140060.

11. Garrido-Urbani S, Jaquet V, Imhof BA. ROS and NADPH oxidase: key regulators of tumor vascularisation. Med Sci (Paris). 2014; 30: 415-21. doi: 10.1051/ medsci/20143004016.

12. Chen S, Meng XF, Zhang C. Role of NADPH oxidasemediated reactive oxygen species in podocyte injury. Biomed Res Int. 2013; 839761. doi: 10.1155/2013/839761.

13. Pick E. Role of the Rho GTPase Rac in the activation of the phagocyte NADPH oxidase: outsourcing a key task. Small GTPases. 2014; 5: e27952. doi: 10.4161/sgtp.27952.

14. Kowluru A, Kowluru RA. Phagocyte-like NADPH oxidase [Nox2] in cellular dysfunction in models of glucolipotoxicity and diabetes. Biochem Pharmacol. 2014; 88: 275-83. doi: 10.1016/j.bcp.2014.01.017.

15. Kim GS, Jung JE, Niizuma K, Chan PH. CK2 is a novel negative regulator of NADPH oxidase and a neuroprotectant in mice after cerebral ischemia. J Neurosci. 2009; 29:1477989. doi: 10.1523/JNEUROSCI.4161-09.2009.

16. Meggio F, Pinna LA. One-thousand-and-one substrates of protein kinase CK2? FASEB J. 2003; 17:349-68.

17. Pinna LA. Protein kinase CK2: a challenge to canons. J Cell Sci. 2002; 115: 3873-8.

18. Kim GS, Jung JE, Narasimhan P, Sakata H, Yoshioka H, Song YS, Okami N, Chan PH. Release of mitochondrial apoptogenic factors and cell death are mediated by CK2 and NADPH oxidase. J Cereb Blood Flow Metab. 2014; 32: 720-30. doi: 10.1038/jcbfm.2011.176.

19. Blanquet PR, Mariani J, Fournier B. Temporal assessment of histone $\mathrm{H} 3$ phospho-acetylation and casein kinase 2 activation in dentate gyrus fromischemic rats. Brain Res. 2009; 1302: 10-20. doi: 10.1016/j.brainres.2009.09.030. 
20. Kikuchi K, Tanaka E, Murai Y, Tancharoen S. Clinical trials in acute ischemic stroke. CNS Drugs. 2014; 28: 92938. doi: 10.1007/s40263-014-0199-6.

21. Cojocaru IM, Cojocaru M, Sapira V, Ionescu A. Evaluation of oxidative stress in patients with acute ischemic stroke. Rom J Intern Med. 2013; 51:97-106.

22. Rodrigo R, Fernández-Gajardo R, Gutiérrez R, Matamala JM, Carrasco R, Miranda-Merchak A, Feuerhake W. Oxidative stress and pathophysiology of ischemic stroke: novel therapeutic opportunities. CNS Neurol Disord Drug Targets. 2013; 12:698-714.

23. Montenarh M. Protein kinase CK2 and angiogenesis. Adv Clin Exp Med. 2014; 23: 153-8.

24. Cozza G, Pinna LA, Moro S. Kinase CK2 inhibition: an update. Curr Med Chem. 2013; 20: 671-93.

25. Angeloni C, Prata C, Dalla Sega FV, Piperno R, Hrelia S. Traumatic brain injury and NADPH oxidase: a deep relationship. Oxid Med Cell Longev. 2015; 2015: 370312. doi: 10.1155/2015/370312.

26. Chuong Nguyen MV, Lardy B, Paclet MH, Rousset F, Berthier S, Baillet A, Grange L, Gaudin P, Morel F. NADPH oxidases, Nox: new isoenzymes family. Med Sci (Paris). 2015; 31: 43-52.

27. Tsai MH, Lin ZC, Liang CJ, Yen FL, Chiang YC, Lee CW. Eupafolin inhibits PGE2 production and COX2 expression in LPS-stimulated human dermal fibroblasts by blocking JNK/AP-1 and Nox2/p47(phox) pathway. Toxicol Appl Pharmacol. 2014; 279: 240-51. doi: 10.1016/j. taap.2014.06.012.
28. Park HS, Lee SM, Lee JH, Kim YS, Bae YS, Park JW. Phosphorylation of the leucocyte NADPH oxidase subunit p47(phox) by casein kinase 2: conformation-dependent phosphorylation and modulation of oxidase activity. Biochem J. 2001; 358:783-90.

29. Wang XL, Li Y, Zhao Q, Min ZL, Zhang C, Lai YS, Ji $\mathrm{H}$, Peng S, Zhang Y. Design, synthesis and evaluation of nitric oxide releasing derivatives of 3-nbutylphthalide as antiplatelet and antithrombotic agents. Org Biomol Chem. 2011; 9: 5670-81. doi: 10.1039/c1ob05478c.

30. Nito C, Kamiya T, Ueda M, Arii T, Katayama Y. Mild hypothermia enhances the neuroprotective effects of FK506 and expands its therapeutic window following transient focal ischemia in rats. Brain Res. 2004; 1008:179-85.

31. Ling JJ, Ji H, Wang XL, Zhang YH, Zhang C, Song HZ, Li J, Zhao M, Ping FF, Qian J. 5d, a novel analogue of 3-n-butylphthalide, protects brains against nervous injury induced by ischemia/reperfusion through Akt/Nrf2/NOX4 signaling pathway. RSC Adv. 2015; 5: 69583. 